\title{
Evaluation of Airway resistance and Spirometry in Petrol Pump Workers: A Crossectional study
}

\author{
S. P. Choudhari ${ }^{1}$, R. S. Doiphode ${ }^{1}$, U. S. Zingade ${ }^{2}$, \\ Dr. Ahmed Munibuddin ${ }^{1}$, Dr Khaled Mohsin Badaam ${ }^{1}$ \\ 1. Department Of Physiology, Govt. Medical College, Aurangabad. \\ 2. Department Of Physiology, BJ Medical College, Pune.
}

\begin{abstract}
Background: The rapidly increasing number of automobiles in most cities has led to an increase in air-pollution and has become a cause of grave concern. Air pollutants derived from automobile exhaust and fuel vapours have become a major health hazard for certain groups of our society by virtue of their occupation.

Objective: To evaluate the airway resistance and spirometry parameters of petrol-pump workers.

Design: The present study was carried out on 40 male petrol pump workers in the age-group of 20-40 years who were working at petrol-pumps for more than 5 years. Spirometry parameters such as Forced Vital Capacity $(F V C)$, Forced Expiratory Volume in the first second $\left(F E V_{1}\right)$, Forced Expiratory Flow [FEF $F_{(25-75 \%)}$, Slow Vital capacity (SVC), Maximum Voluntary Ventilation (MVV) and Plethysmography parameters like Airway Resistance $\left(R_{a w}\right)$ were recorded on a whole body Plethysmograph (Elite Dx model, Med graphics, USA ). The results were compared with that of the controls.

Results: $F V C, F E V_{1}, F E F_{(25-75 \%)}, S V C$, and MVV showed a significant decline whereas Raw was increased in petrol pump workers as compared to controls.

Conclusions: Petrol pump workers have significantly lower lung functions as measured by spirometry \& airway resitance is significantly raised in them as compared to controls.
\end{abstract}

Keywords: Spirometry, Plethysmography, Petrol pump workers.

\section{Introduction}

In $21^{\text {st }}$ Century, everyone is victim of pollution and facing its consequences in the form of global warming, acid rains, melting of Antarctica glaciers, floods and extremes of heat \& cold.

Human exposure to air pollution has been attributed to cause severe health hazards, especially in urban areas where pollution levels are often high. [1]

One of the major causes of air pollution is the automobile exhaust derived air pollutants, which has become a matter of concern due to the enormous increase in number of automobiles in the cities.

Certain groups of our society, by virtue of their occupation, face an increasing threat of its adverse health effects due to automobile exhaust and fuel vapours (Petrol \& Diesel)

The combined effects of the above two may result in accelerated decline in lung functions. [2]

Therefore, the present study was conducted to evaluate the effect of exposure to fuel vapours \& automobile exhaust in petrol pump workers, who have completed more than 5 years of service at fuel stations \& assess the airway resistance \& spirometry parameters of lung functions in them.

Study Design: Crossectional Study.

\section{Materials And Methods}

Cases: 40 male petrol pump workers with exposure period of more than 5 years to fuel vapours $\&$ vehicular exhaust in the vicinity of their work station were studied at Pulmonary Function Test (PFT) laboratory, Department of Physiology, Govt. Medical College, Aurangabad.

Controls: Age, height, weight matched healthy subjects of same number from similar socioeconomic status were selected as controls for the study.

Age group of the study participants was 20-40 years.

Petrol pump workers with past history of major respiratory illness like Tuberculosis, pleural effusion, COPD, asthma \& smokers were excluded from the study.

PFT were recorded on Whole Body Plethysmograph (Elite Dx model Med graphics, USA).

Spirometry parameters like FVC, $\mathrm{FEV}_{1}, \mathrm{FEF}_{(25-75 \%)}$, SVC and MVV were recorded in sitting position outside the body box of machine. The standard protocol and precautions for the spirometry procedure as per American Thoracic Society guidelines were followed. Three recording were taken and the best effort was included in the results. 


\section{Airway Resistance measurement: (Raw)}

The subject was asked to sit inside an airtight chamber and asked to inhale \& exhale to a particular volume, a shutter then drops across the breathing tube. The subject makes respiratory efforts against the closed shutter, causing chest volume to expand and decompress the air in the lungs. The readings of the Raw were recorded. Advantage of Plethysmography is that all compressible gas in thorax is measured, regardless of whether compressed area is ventilated or not.

All the recordings were done between 9 am to 11 am to eliminate any effect of diurnal variation. Percent predicted values for all the parameters were taken into consideration for statistical analysis to eliminate the effect of confounding factors like Age, height, weight on different lung parameters.

Unpaired ' $t$ ' test was applied for comparison between the two groups.

\section{Results}

Table1: Baseline Characteristics

\begin{tabular}{|l|l|l|}
\hline Parameter & Cases & Controls \\
\hline Age (years) & $29.5 \pm 5.7$ & $30.4 \pm 5.5$ \\
\hline Weight (kilograms) & $54.5 \pm 9.7$ & $52.4 \pm 8.9$ \\
\hline Height (centimeters) & $163.2 \pm 6.6$ & $164.9 \pm 7.2$ \\
\hline BMI $\left(\mathrm{kg} / \mathrm{m}^{2}\right)$ & $20.46 \pm 2.22$ & $19.27 \pm 1.72$ \\
\hline
\end{tabular}

Table 2: Comparison of percent predicted values of Lung Functions

\begin{tabular}{|l|l|l|l|}
\hline \multirow{2}{*}{ Lung Parameters } & Test Group & Control group & \multirow{2}{*}{ 'p' value } \\
\cline { 2 - 3 } & Mean \pm SD & Mean \pm SD & \\
\hline FVC $(\mathrm{L})$ & $68.9 \pm 7.7$ & $88.9 \pm 5.4$ & \\
\hline FEV1(L) & $68.7 \pm 5.6$ & $90.4 \pm 4.2$ & $0.0001^{* *}$ \\
\hline FEF $25-75 \%(\mathrm{~L} / \mathrm{sec})$. & $71.6 \pm 18.3$ & $85.5 \pm 12.4$ & $0.0001^{* *}$ \\
\hline SVC $(\mathrm{L})$ & $75.6 \pm 10.6$ & $97.3 \pm 18.7$ & $0.0001^{* *}$ \\
\hline MVV $(\mathrm{L} / \mathrm{min})$ & $78.4 \pm 17.3$ & $99.7 \pm 13.3$ & $0.0001^{* *}$ \\
\hline Raw $\left(\mathrm{cm} \mathrm{H}_{2} \mathrm{O} / \mathrm{L} / \mathrm{sec}\right)$ & $114.7 \pm 5.17$ & $55.9 \pm 1.48$ & $0.0001^{* *}$ \\
\hline
\end{tabular}

** Highly significant

\section{Discussion}

'Present study indicates that, all the petrol pump workers showed decline in their lung volumes and capacities and increased Raw, thereby confirming that regular exposure to fuel vapours (hydrocarbons) and automobile exhaust for more than 5 years ( $8 \mathrm{hrs}$ of duty) have adverse effect on the respiratory system.

The decreased values of lung functions may indicate underlying lung dysfunction due to air pollution caused by automobile exhaust \& fuel vapours.

Vehicular exhaust is estimated to account for $60-70 \%$ of total air pollution and this is the worst type of pollution because it is generated at the ground level or breathing level causing more harm.

Automobile exhaust produces volatile organic compounds, suspended particulate matter (SPM), oxides of nitrogen, Carbon monoxide $(\mathrm{CO})$ \& Sulphur dioxide $\left(\mathrm{SO}_{2}\right)$ which adversely affects the respiratory system.

The particles emitted from the vehicular exhaust which are more than $10 \mu$ size are held in the Upper Respiratory Tract \& particles less than $10 \mu$ size accumulate in the lungs \& produce respiratory impairment. Particulate matter of the size of $2.5 \mu$ and $10 \mu$ and $\mathrm{NO}_{2}$ has been found to be significantly associated with reduced FVC. Similar effects of automobile exhausts on the $\mathrm{FVC}$ and $\mathrm{FEV}_{1}$ have been reported in tunnel and bridge workers \& traffic police. [3-6]

FEF is considered a fairly good test to identify early small airway disease. [7-9]

The findings of the present study indicate that small airways probably bear the brunt of the air pollution \& fuel vapour related lung injury. This finding is in agreement with most studies on pollution inflicted changes in lung functions. $[5,10,11]$

In combination with particulate pollutants, $\mathrm{SO}_{2}$ and $\mathrm{NO}_{2}$ have a greater chance to reach the deeper parts of the lungs. The gaseous pollutants may also alter the properties and concentration of surfactant and may thus contribute to the early closure of small airways. Many terminal bronchioles may be compromised before other PFTs like $\mathrm{FEV}_{1}$ are affected. [7] 
Raw is strongly correlated with lung volume because as the lungs expand, the airways also dilate. If lung volume decreases, Raw increases reflecting the effect of decreasing lung volumes on airway caliber. [12] Present study reveals increased values of Raw, indicating airway related broncho-constriction, due to fuel vapours and chemical substances emitted from automobile exhaust.

Limitation of the present study is small sample size which also makes it difficult to evaluate time dependent derangements in lung function.

Further research especially cohort studies and multicentric studies needs to be done in petrol pump workers to substantiate the study results and also to find out the contribution of various pollutants in causing impaired lung functions.

\section{Conclusions}

The study revealed that petrol-pump workers are highly vulnerable for respiratory impairment due to their occupation. More than 5 years of exposure to automobile exhaust \& fuel vapours in petrol pump workers showed decline in the efficiency of lung functions and increase in Airway resistance.

\section{Recommendations:}

1) Periodic Health check-up of fuel station workers for Pulmonary Function Test once in a year.

2) To provide antipollution masks to fuel station workers.

3) Health education of fuel station workers regarding adverse effects of fuel vapours and automobile exhaust.

\section{Acknowledgements}

The authors are thankful for the active participation of all the study participants. We are also thankful to the fuel station workers and cooperation from owners of Petrol Pumps, Aurangabad, Maharashtra, India.

\section{References}

[1]. Patil PB, Shivare TA. Kurukshetra Magazine: Ministry of Rural Development, Govt. of India, 2004;53(1):28.

[2]. Chawla A, Lavania AK. Indian J Physiol Pharmacol 2008;52

[3]. Evans RG, Webb k, Homan S, Ayres SM. Am J Ind Med 1988;14(1):25-36

[4]. Rostogi SK, Gupta BN, Hussain T. Ind J Occup Health 1991;34(2):67-74.

[5]. Mohan RN, Patel TS, Raiyani CV et al. Indian J Physiol Pharmacol 1992;36(1):60-64.

[6]. Ingle ST, Panhpande DG, Wagh ND et al. Ind Health 2005;43(4):656-662.

[7]. Cotes JE. Lung function assessment and application in medicine. $5^{\text {th }}$ edi. Oxford Blackwell Scientific Publication 1993 pg 122

[8]. McFadden ER, Linden DA. Am J Med 1972;52:725-27.

[9]. Scanlon PD, Hankinson J. Occupational and environmental respiratory disease. St. Louis Missouri. Mosby Year Book Inc. 1996 Pg $39-52$.

[10]. Zuskin E, Mustajbejovic J. Am J Ind Med 1994;26(6):771-83.

[11]. Sourza MB, Saldiva PHN, Pope CA, Chest 1998;113:1312-18.

[12]. John D. Zoidis. Care April/May 2003. 